\title{
9 Dependence and autonomy in sub-national island jurisdictions: the case of the kingdom of the Netherlands
}

\author{
Gert Oostindie
}

\section{INTRODUCTION: THE COSTS AND BENEFITS OF CARIBBEAN DECOLONIZATION}

Two centuries after the Haitian revolution the decolonization of the Caribbean still seems incomplete; nor is this situation likely to change in the near future. Of the four major European colonizers, only Spain has been forced to retreat from the region. With Puerto Rico (3.8 million people) and the US Virgin Islands (110 000), the USA has the largest share of the population in the non-sovereign Caribbean, followed by France with its départements d'outre-mer (DOM, roughly 1 million), The Netherlands with the Netherlands Antilles (180000) and Aruba (90000), and the UK with its overseas territories $(155000)$. In all, some $15 \%$ of the 37 million people living in the Caribbean today reside in non-sovereign territories.

Any analysis of political and development issues in the Caribbean must take stock of the fact that the region in itself is small, and that most Caribbean territories are too. Small islands need not necessarily suffer from their scale - some analysts point at advantages such as flexibility which come with smallness. Yet the odds are against small states when it comes to political clout. They are "mostly acted upon by much more powerful states and institutions... For all that, it is vulnerabilities rather than opportunities...that come through as the most striking manifestations of the consequences of smallness in global politics" (Payne, 2004, p. 634).

Another dimension of crucial importance in the Caribbean context is constitutional status. Sovereignty is a mixed economic blessing for micro-states generally. Even if sovereign micro-states may prove to be remarkably viable, non-sovereign territories world-wide definitely score better by economic standards (Armstrong et al., 1998; Armstrong and Read, 2000). The Caribbean does not present an exception to this rule, as recently documented in a thorough analysis of both Caribbean and Pacific island economies, including their demographic characteristics (McElroy and Sanborn, 2005), and of the Caribbean only (McElroy and de Albuquerque, 1995). In the Caribbean, which contains an extremely heterogeneous collection of both real and virtual islands, ${ }^{1}$ there is an evident positive correlation between non-sovereignty and standards of living (as measured by conventional economic variables), and to some degree between non-sovereignty and good governance, including guarantees of human rights and liberties (Oostindie and Klinkers, 2003, passim).

This observation certainly applies if the three major countries of the Caribbean are included in the equation. Cuba (11.3 million), Haiti ( 8.3 million) and the Dominican Republic ( 8.6 million) together account for three-quarters of the total Caribbean 
population. These three states, giants by Caribbean standards yet still small by international criteria, boast a history of sovereignty dating back one (Cuba) to two (Haiti) centuries. At the close of the twentieth century Haiti was the poorest country in the Caribbean. In a list of 28 entities, the Dominican Republic was in twenty-third position, and Cuba twenty-fifth, in GNP per capita (Bulmer-Thomas, 2001; Oostindie and Klinkers, 2003, pp. 154-155). Caribbean evidence thus suggests that sovereignty is a drawback for economic development, not only for the young micro-states of the region, but even for the largest states with a history of independence dating back one to two centuries.

When the 'big three' are excluded from the equation, one is left with four formal colonial subdivisions within the Caribbean region. Most of the former British West Indian colonies attained their sovereignty between 1962 (Jamaica) and 1983 (St Kitts and Nevis). Puerto Rico and the US Virgin Islands have remained attached to the USA. The French colonies were fully integrated into the French state in 1946 as départements d'outre-mer (DOM). The former Dutch colony of Suriname became an independent republic in 1975, whereas the six Dutch islands in the Caribbean are still part of the Kingdom of the Netherlands.

Glossing over the intermediate states of Cuba, the Dominican Republic and Haiti, we may observe that all the remaining Caribbean territories are small or even tiny by international standards. Puerto Rico has a population of 3.9 million, Jamaica 2.7 million, Trinidad and Tobago 1.1 million. All others are below the one million mark. At the extreme end we find independent nations such as St Lucia with 166000 people, St Vincent and the Grenadines with 118000 , and St Kitts and Nevis with only 47000 people. With the exception of Puerto Rico, the non-sovereign islands all belong to the category of the smallest Caribbean territories.

What is the situation of the postwar sovereign states compared to those that opted to retain some sort of constitutional and 'neocolonial' attachment to their metropolis? It is difficult to offer any hard evidence of a direct causality, but it is obvious that most of the non-sovereign entities are better off in terms of per capita incomes, assuming, that is, that no significant contrasts in overall distribution of income exist (BulmerThomas, 2001; Oostindie and Klinkers, 2003, pp. 154-155). Out of the 10 richest entities in the Caribbean in the late twentieth century, nine are non-sovereign. Out of these 10 , only the Bahamas is an independent state. Even when the big three are excluded, the 10 poorest countries include only one non-sovereign island, the tiny UK overseas territory of Montserrat, beleaguered by quite unique environmental hazards.

A particularly painful contrast is provided by the three Guyanas. The former British colony of Guyana and the former Dutch colony of Suriname are among the three poorest states of the Caribbean, whereas the French department of Guyane is among the richest. Another indication of the costs of independence is suggested by the divergent development within the former Dutch Caribbean. Suriname has experienced a continuous deterioration since independence, whereas the Dutch islands, with some significant contrasts between them, have maintained their position within the category of the privileged.

For present purposes we need not discuss at any length the variables explaining the better economic performance and higher standards of living of non-sovereign islands. Certainly, direct metropolitan monetary transfers are not the only or necessarily the most important factor. Being embedded in a larger and generally stable constitutional entity serves to strengthen these dependent territories' institutional environment, with 
ensuing positive effects for local business and governments and enhanced credibility for international finance. Then there is the major advantage of duty-free or preferential access to metropolitan markets. And, of course, the virtual guarantee that in extreme cases - particularly when natural disasters such as hurricanes wreak havoc - there will be immediate and relatively generous metropolitan disaster relief.

What of the functioning of democracy and particularly guarantees of human rights and liberties? The first and perhaps most important conclusion to be drawn is that the record of the Commonwealth Caribbean has been remarkably positive, in spite of enormous economic problems compounded by the ever more evident threats provided by international crime. This is a major accomplishment. Yet the small number of countries which have suffered serious disruptions in their postwar democratic development - Guyana, Grenada and Suriname; some would argue that Jamaica under Michael Manley's early socialist experiment should be added to this list - are all young independent states. Independent and non-sovereign states alike have experienced serious problems with the quality of governance, but no suspension of democratic institutions was ever enforced or seriously considered among the latter. In these dependent territories standards of governance are defined and if necessary enforced, by the metropolis.

The same metropolis also guarantees the territorial integrity of the non-sovereign unit. This may seem to be a hypothetical benefit, inasmuch as intra-regional warfare seems a phenomenon of the distant past in the Caribbean. Yet there have been some such threats in the postwar Caribbean, for example incidental Venezuelan claims against Trinidad and Tobago and the Netherlands Antilles, Guatemalan claims against Belize, and Guyanese-Surinamese skirmishes. So this potential benefit of being under the protection of a larger and more powerful external state cannot be dismissed and is indeed appreciated (e.g. Oostindie and Verton, 1998, pp. 54-55).

There is another major benefit to non-sovereignty. Migration to the USA and Canada has become a crucial strategy of survival for millions of people from the sovereign Caribbean. Potential migrants have to endure difficult, lengthy, often humiliating, and not always successful procedures to gain admittance, the right of abode, and eventually citizenship. None of this applies to the citizens of the nonsovereign Caribbean when they seek to migrate to their metropolis. (One significant but temporary exception to this was the restrictive British Dependent Territories Citizenship, from 1981 to 2002.) Even if per capita incomes are high in these territories by sovereign Caribbean standards, they clearly fall short of metropolitan standards of living. This, in addition to other pull factors such as educational opportunities, or the broadening of one's horizon, has persuaded large numbers in the non-sovereign Caribbean to move to their respective metropolis. They do not encounter major legal obstacles because they have metropolitan citizenship and thus the right of abode in the metropolis.

Thus, in at least three dimensions - per capita income, the protection of the citizenry against external or internal threats (particularly the functioning of a representative democracy and guarantees of civil rights and liberties) and with regard to migration - there are evident benefits to non-sovereignty. Yet there are also some disadvantages. Metropolitan protectionism and the frequently massive accompanying financial transfers may have boosted per capita income, but they have also served to create uncompetitive consumer economies and, particularly for Puerto Rico and the French DOMs, 'aid addiction'. Likewise, the easy migration outlet may have reduced 
population pressure in these densely inhabited islands, but at the same time may have caused a brain drain and an almost exclusive orientation towards the metropolis, one which serves to further isolate the islands from their Caribbean surroundings.

Finally, there is a fourth dimension: the ideological and psychological significance of the sheltered constitutional status of non-sovereignty. This is perhaps a moot point. The rhetoric of political nationalism invariably starts with the axiom that ending colonial hegemony is a prerequisite for 'real' national development. It is striking how in non-sovereign territories many politicians firmly opposed to independence still pay lip-service to the presumed ultimate objective of becoming an independent state. As a former Antillean prime minister once confided: "It is your pride, your dignity!" Such convictions, however, do not reorient the past or present actual performances by the political elite.

For all practical purposes politicians in the non-sovereign Caribbean aspire to maintain the many material advantages of the postcolonial bond, while at the same time securing maximum autonomy. This is a recipe for at times heated contestations over the thin dividing line between outside control and internal authority. Such contestations tend to occur not only in strictly administrative and political terms, but equally as an issue of a besieged national identity. All this becomes evident time and again, whether in Puerto Rico, Martinique, Curaçao or Montserrat. The enormous asymmetry inherent in metropolitan-(post)colonial relations is a permanent frustration on the Caribbean side, a frustration often experienced as a minor irritant in the metropolitan centres of power. This is not only a problem felt by local administrators. Certainly in the Caribbean context there is a wider collective ambivalence towards, if not outright distrust of, the metropolis. After all, the metropolis may be useful and accommodating today, but it started out in the region as a crass colonial power populating its plantation colonies with African slaves and Asian indentured labourers. Their descendants are as keenly aware of this historical background as of the fact that the metropolitan appreciation of said background is usually very limited.

It is obvious that there is no way - or need for that matter - to establish objectively which dimension or which combination of the four dimensions outlined above should be rated as decisive in assessing the costs and benefits of independence. The different actors in this postcolonial double bind - Caribbean governments and their individual citizens, Caribbean citizens as potential migrants and metropolitan governments have widely divergent perspectives and interests. There is therefore no foregone conclusion, but there is one hard empirical fact: the overwhelming majorities within the non-sovereign Caribbean do not want to consider any change of status which would endanger the obvious advantages of their postcolonial dependency. Plebiscites, opinion polls and electoral processes have demonstrated time and again that the overwhelming majority of citizens in the non-sovereign Caribbean islands, and in the one continental territory, French Guyana, are adamantly opposed to a move towards full independence. The option of full independence for small territories remains widely resisted (Oostindie and Verton, 1998; Oostindie and Klinkers, 2003, pp. 220 221; Baldacchino, 2004).

Meanwhile the political legitimacy of the choice against independence, both for the Caribbean and world-wide, has become stronger over the years. The United Nations affirmed as early as 1960 , and again in 1970, that any status including free association or integration within the metropolis was acceptable as long as this option 
was freely chosen by a former colony's citizenry (Oostindie and Klinkers, 2001, Vol. I, pp. 131-132; Vol. III, p. 77). The growing empirical evidence of the high costs of sovereignty for young micro-states provided additional argumentation. Indeed, as McElroy and Sanborn conclude for both Caribbean and Pacific islands, there is abundant "scientific basis for their [non-sovereign islands'] persistent choice to retain metropolitan linkages and the favourable benefits of the political economy of dependence" (McElroy and Sanborn, 2005, p. 10). Indeed, the findings of this scholarly work firmly coincide with common Caribbean sense!

This chapter will now review and analyse the past decolonization process of the Dutch Caribbean - initially comprising Suriname and the six-island Netherlands Antilles - and consider recent developments in the light of the dynamic relationship between the Kingdom of the Netherlands and its remaining Caribbean territories. A short conclusion will reflect on the wider relevance of this particular case.

\section{THE FIRST PHASE OF DUTCH DECOLONIZATION: TOWARDS THE 1954 STATUUT}

The core of Dutch colonialism was not situated in the Caribbean but rather in the Dutch East Indies. Here classic colonialism - based on economic and geopolitical interests combined with administrative zeal - was abruptly ended through a classical decolonization struggle characterized by bloody battles and protracted negotiations which would poison postcolonial relations. In only seven years - marked by the Japanese occupation in 1942, the unilateral proclamation of independence in 1945 and the transfer of sovereignty in 1949 - the Netherlands lost the Dutch East Indies, a colony which was, many thought, a mixed metaphor: both the cork which kept the Dutch economy floating, and the Dutch ticket to the status of player in world politics. At the end of the day the loss of Indonesia would turn out to be no economic drama but it did reduce the significance of the Netherlands in international politics.

Concurrently with this arduous process, The Hague developed a decolonization policy for its Caribbean colonies. The outcome was the Statuut or Charter of the Kingdom of the Netherlands, proclaimed in 1954. The Statuut defined the Kingdom as a voluntary relationship between three equal and internally autonomous countries, being the Netherlands, Suriname and the six Caribbean islands forming the Netherlands Antilles. A middle path had been chosen between the two extremes full sovereignty for the former Caribbean colonies or, conversely, complete integration in the metropolis as provinces - neither of which was seriously discussed by any of the partners involved.

As stated in the preamble of the Statuut, the three countries would "take care of their own interests autonomously, manage communal affairs on an equal footing, and accord each other assistance". The Charter defined foreign policy, defence, citizenship, and the safeguarding of proper governmental administration as matters of common interest to be governed by the Kingdom of the Netherlands. This Kingdom government was simply delineated as the ruling Dutch cabinet, expanded to include one plenipotentiary minister for each of the two Caribbean territories. The initial concept to inaugurate a Kingdom parliament to which this Kingdom government would be accountable was eventually abandoned by all parties. At one point in the long-winded negotiations all parties agreed that this would be too 


\section{G. Oostindie}

complicated a structure, and too much of a drain on the limited Caribbean political and administrative resources. For pragmatic reasons the simpler variation was chosen, which up until today reflects the 'democratic deficit' of a government without a corresponding parliament.

The Statuut rests on notions of 'equality' and 'reciprocal assistance', which, because of the asymmetrical balance of power, are totally fictitious. That was already obvious in 1954. The initial formulae were actually not invented with an eye to Caribbean decolonization but, rather, to World War II conditions, where the exiled Dutch cabinet in London hoped to persuade the Indonesian nationalists to remain within a modernized postwar Kingdom of the Netherlands. There is a double irony here if we take the demographics into consideration. In 1940 the Netherlands had about nine million inhabitants, while Indonesia had 70 million. The Hague was therefore offering 'equality' to a population many times bigger than its own. At the same time Suriname had only 140000 inhabitants and the Dutch Antilles 108 000. In the negotiating process leading to the Charter, West Indian politicians capitalized on the accommodations which The Hague had originally created specifically for the East Indies. Hence the fictitious 'equality' between two Caribbean nations and their metropolis, which, in reality, dwarfs them.

The Statuut has been the foundation of the transatlantic Kingdom for half a century. In the preamble it was stated that the Charter would not be an 'eternal pact'. In reality it seems to have been just that: a virtually unchangeable arrangement. Certainly its membership has changed, with Suriname attaining independence in 1975; Aruba seceding from the Netherlands Antilles and acquiring a separate status as a territory within the Kingdom of the Netherlands in 1986; and yet more changes in store. But the contents of the Charter have been preserved to the letter, just as they were in 1954. Unfortunately this absence of change can be attributed not to the constitution's luminosity but rather to its rigidity. As the Charter itself posits, no change whatsoever can be implemented unless all partners agree.

\section{THE DUTCH PREFERENCE FOR A FULL RETREAT}

Until the late 1960s all three countries of the Kingdom were by and large satisfied with the Statuut. For The Hague the turning point came in May 1969 with the revolt of Curaçao. A labour conflict with strong political and racial connotations ended with rioters burning down central parts of the capital, Willemstad. According to the Charter, the government of the Antilles had the right to ask for military help from the Dutch government, and the latter had to abide by that request. Within hours Dutch marines were patrolling the smouldering streets of Willemstad. This intervention sparked a new and unenthusiastic awareness in the Netherlands of its remnants of empire. The Hague now moved to the position that its relationship with the Caribbean parts of the Kingdom did not contain significant positive interests and implied many uncalled-for risks.

There are three main considerations behind this reluctance, which has since been characteristic of the Dutch attitude. Initially the most important concern was the awareness that the Charter, while entrusting the responsibility for guaranteeing good governance in the overseas territories to the Kingdom government, at the same time leaves this government little opportunity for preventive action in view of the domestic 
autonomy awarded in the same document. So, from a Dutch perspective, The Hague had little to do with the origins of the local discontent which sparked the 1969 riots, yet was obliged to intervene and ended up being unduly criticized for neocolonial behaviour. Dutch policy therefore needed to disentangle itself from similar future obligations by either simply terminating the postcolonial relationship, or conversely becoming ever more interventionist in order to prevent new potential embarrassments from developing. The first line was dominant until roughly 1990, the second ever since.

The second consideration lies in the economic realm. The expectation expressed in the Charter that mutual assistance would help narrow the gap in standards of living between the various parts of the Kingdom proved to be an illusion. Admittedly, the relatively generous Dutch development aid has helped Aruba to attain economic stability and hence its present very high per capita income. In contrast, neither preindependence Suriname nor the contemporary Antilles has been successful in bridging the gap with the ever-richer metropolis. Today Dutch politicians complain of Antillean 'aid addiction' and claim that no country in the world receives as much per capita aid as the Netherlands Antilles. These are false exaggerations, and certainly the assistance extended to the islands is of no serious significance to the Dutch Treasury (Oostindie and Klinkers, 2003, pp. 222-223). Development aid is extended along with continuous reminders of the need for 'self-reliance'. Meanwhile, the reality is that Caribbean reliance on Dutch economic support has simply increased.

Over time, a third, mainly domestic, concern has gained ever more significance for Dutch politicians: unease with the unrestricted migration channel from the Dutch Caribbean to the metropolis. By the early 1970s some 40000 people from the Antilles and Suriname had settled in the Netherlands. Today there are over 320000 Dutch with Surinamese backgrounds and another 130000 with Antillean or Aruban roots. The influx of migrants from Suriname has levelled out after open access was curtailed with independence. Antilleans and Arubans, however, enjoy Dutch nationality and have the right to settle in the Netherlands. As lower-class juvenile migration from Curaçao has created public order problems in Dutch towns over the past decade, this open channel has come under serious attack in Dutch politics. (There is a political divide over the question of whether free access of Antilleans and Arubans should be curtailed as such. A centre-right majority in parliament has urged the centre-right cabinet to devise such draconian legislation. This project led to draft legislation in 2005 but is likely to fail because of both juridical and pragmatic obstacles. Meanwhile, the whole spectrum of Dutch political parties, from the far right to the left, now favours tight controls on deviant Antillean youths. There is widespread support for unconventional policies. Thus in January 2006 the municipality of Rotterdam, claiming that young Curaçaoans are the most criminal group in the country's second city, presented a new project which will oblige young Antilleans to be either pursuing their education, in a job or in some sort of judicial trajectory.)

\section{THE INDEPENDENCE OF SURINAME (1975)}

With few overall benefits, little positive engagement, limited administrative powers yet many responsibilities, it is no wonder that the Netherlands has attempted since 1970 to disentangle itself from its Caribbean dependencies. There are decisive legal 
complications, however, since dismantling the Kingdom would imply changing the Statuut. To accomplish this, all partners involved would need to agree. This has proved to be highly problematic. The Dutch managed to strike a deal on this with Suriname, but failed to do so with the islands.

Suriname became independent in 1975 in a highly unusual and fast-track political process which defied all claims of the Kingdom government as a patron of good governance. Certainly there was a nationalist, pro-independence movement in the country, mainly catering to the Afro-Surinamese in a society deeply divided along ethnic lines. The mainly Afro-Suriname government headed by Prime Minister Henck Arron would celebrate the transfer of sovereignty as if it had been a hard-won victory, which it certainly was not.

The dominant sentiment in The Hague was no less anti-colonial, albeit especially with an eye for the Dutch image, and a Dutch weighing up of costs and benefits. This was really modern paternalism dressed up as progressive policy. The centre-left cabinet of Joop den Uyl managed to accomplish the transfer of sovereignty in just 20 months. The population of Suriname was never directly invited to offer its opinion on the transfer of sovereignty. Neither of the two governments had any interest in staging a referendum: both sides assumed, probably quite correctly, that a majority would oppose independence.

During these 20 months of negotiations, the mainly Hindustani opposition had little faith in either the process or its outcome. Meanwhile, the two governments watched helplessly as one-third of the population of Suriname voted with their feet, choosing to live in the cold European motherland rather than staying in the new republic. In the end the transfer of sovereignty was only achieved because at the critical moment in the parliament of Suriname there was a majority of just one vote in favour of independence. The Dutch parliament agreed wholeheartedly with this wafer-thin majority, while the Antillean assembly did not object as long as there were no implications for its own non-sovereign status.

In the three decades that have passed since the transfer of sovereignty, the hopedfor 'model decolonization' has proved to be a disappointment. Suriname received a relatively generous dowry of 3.5 billion Dutch guilders or about 10000 guilders per capita (around $€ 10000$ per capita at current rates). The continuation of development aid was pledged. Yet this largesse did not prevent economic decline: many politicians feel that it undermined the economy, and some economists lend credence to this (e.g. van Dijck, 2001). Current per capita income in Suriname is among the lowest in the Caribbean. Moreover, even if the dowry to Suriname has been much criticized as extravagant, since 1975 the Netherlands has spent twice as much on the six Antillean islands taken together, and per capita three times as much on the islands' population, as on the poorer Surinamese (Oostindie and Klinkers, 2003, p. 165).

This is not all. The demographic growth of the Surinamese population has been heavily concentrated in the Netherlands. The political and administrative history of the republic has had many low points, of which the military dictatorship of the 1980s was the nadir. Informal and illegal sectors have become pervasive in the economy and society, a development that successive governments have been either unwilling or unable to redress. Many observers already qualify Suriname as a failing state. It is indeed questionable whether, in the long run, Suriname will be able to survive as an independent state. The Netherlands, still the most important partner, is slowly disengaging itself. Suriname has been trying to strengthen its engagement with the 
Caribbean Community and Common Market (Caricom) countries. But in the long run Brazil, which considers the Guyanas as its backyard, or even Venezuela, may well fill the void left by the Netherlands - possibly via informal dominion, or more likely through settlement and land clearances.

\section{THE NETHERLANDS ANTILLES: DISINTEGRATION WITHOUT SOVEREIGNTY}

In contrast to Suriname, the Antilles has never had a serious pro-independence movement. Over the past decades some political parties have rendered lip service to a parting with the Netherlands in a distant future, but in practice Antillean politicians have simply refused to discuss sovereignty. Much to the annoyance of their Dutch counterparts, they have consistently brushed aside threats that independence would be imposed upon them. After all, they maintain, the Statuut guaranteed that any change was contingent upon their cooperation; and no consensus on the subject of a transfer of sovereignty would be forthcoming from the islands. The predicament of the Republic of Suriname has only added to Antillean reluctance - and in the end induced the Dutch to rethink their stance.

Around 1990 The Hague finally concluded that it would be practically impossible as well as immoral and reproachable by international standards unilaterally to enforce independence upon its remnants of empire in the Caribbean. With this understanding the playing field changed yet again. The debate has since revolved around the question of the boundaries between Caribbean autonomy and the prerogative of the Kingdom - for all practical purposes, this meaning the Netherlands - to play a more active role in Caribbean administration. This is simply a means to a further end in the Dutch view. The Hague's perception is that the overseas governments have too often been incapable or even unwilling to meet international standards of good governance. There is uneasiness about fragile governments, about clear signs of corruption, about the threat of bankruptcy of the Antillean government.

As The Hague thus had to accept the impossibility of a full retreat from the region, the Dutch in the end also conceded to another unsolicited development, namely the internal disintegration of the six-island Netherlands Antilles. In 1986 Aruba received its much desired status aparte, a secession from the Dutch Antilles subject to the condition that the island would have to attain full independence 10 years later. The Netherlands had insisted on this condition, both in the vain hope of breaking the Aruban struggle for a status aparte and to keep the other islands from a similar separatism, which would most probably imply the end of the multi-island Antilles. The Hague at the time still hoped for a transfer of sovereignty to a six-island state of the Antilles. What really followed was predictable. As of 1 January 1986 Aruba started an all-out offensive in order to remove the fatal date of independence from the Statuut. It succeeded in 1996 with the attainment of a permanent separate status within the Kingdom. Henceforward the Charter once again binds three countries.

Much to The Hague's frustration, both the Antillean and the Aruban governments have been wary of complying with the pressure to trade in local autonomy in favour of a strengthening of governmental institutions at the level of the Kingdom. At the same time the Caribbean governments have relied heavily on Dutch support in 
helping them to resolve local problems. In the Aruban case this has worked reasonably well - actually, because of its vigorous liberal economic policy, the island has time and again been promoted as a shining example to the protectionist Antillean government. Over the past decade Willemstad has started to liberalize its economy as well, but a deep crisis remains. National debt by now is almost equal to GDP, unemployment in the formal sector is sky-high and, in spite of the overall, relatively high per capita income, there is outright deprivation in many parts of the Antilles.

Successive Antillean governments have blamed part of their problems on the complicated structure of the Antilles-of-five, a colonial construct which in practice is characterized more by island-centred visions, mutual distrust and chicaneries than by a genuine sense of belonging together. In the early 1990s the Dutch proposed a tradeoff between the islands' preference for breaking up the federal Antilles against their own wish to secure a firmer grip on local governments. This Dutch policy rested on the unwillingness of local politicians to give up autonomy and led to what probably in reaction - was a resurgence of pan-Antillean solidarity.

Debate over the Statuut has been revived since the year 2000. Large majorities of both political parties on the five islands and their electorates, who were given a chance to speak out in a national plebiscite, now opt for an end to the five-island state and want direct relations of each of the islands with the Netherlands. The forms these direct relations may take are multiple. One option is full integration of an individual island or of a combination of these into the Netherlands, as in a departmental or municipal status. Another option is for individual islands to acquire the status aparte Aruba already secured for itself in 1986, that is, the status of an autonomous country within the Kingdom of the Netherlands originally reserved for the six-island Netherlands Antilles only. The option of a continuation of a multi-island Netherlands Antilles is no longer feasible. And, to complete the picture, the option of a collective or insular choice for independence is still one without significant support (see Table 9.1).

Table 9.1 Results of plebiscites in the Netherlands Antilles, 2000-05 (\%)

\begin{tabular}{lcccccc}
\hline & Turnout & $\begin{array}{c}\text { Status quo } \\
\text { (Antilles- } \\
\text { of-five) }\end{array}$ & $\begin{array}{c}\text { Unilateral } \\
\text { link with } \\
\text { the } \\
\text { Netherlands }\end{array}$ & $\begin{array}{c}\text { Full } \\
\text { integration } \\
\text { into the } \\
\text { Netherlands }\end{array}$ & $\begin{array}{c}\text { Autonomous } \\
\text { country } \\
\text { within the } \\
\text { Kingdom }\end{array}$ & Independence \\
\hline Bonaire & 56.1 & 15.9 & 59.5 & n.a. & 24.1 & 0.5 \\
Curaçao & 54.0 & 3.7 & n.a. & 23.6 & 67.3 & 4.8 \\
Saba & 78.0 & 13.0 & 86.0 & n.a. & n.a. & 1.0 \\
St Eustatius & 55.0 & 77.0 & 21.0 & 2.0 & n.a. & 0.6 \\
St Martin & 55.7 & 3.7 & n.a. & 11.6 & 69.9 & 14.2 \\
\hline
\end{tabular}

Source: www.minbzk.nl

Note

The plebiscites were held on: 23 June 2000 (St Martin), 10 September 2004 (Bonaire), 5 November 2004 (Saba) and 8 April 2005 (Curaçao and St Eustatius). The available options were not identical, hence the blanks (n.a.) in the table. Full integration into the Netherlands was understood as some sort of special municipality status within the Dutch administrative apparatus. The option of a unilateral link presupposes slightly more insular autonomy, but always clearly short of the high level of autonomy presently applicable to both Aruba and the Netherlands Antilles. 
On closer inspection the outcomes disclose some interesting contrasts. As expected, the drive for a status aparte within the Kingdom dominates in the two largest entities: Curaçao (with some 130000 inhabitants) and (the Dutch part of) St Martin (nearly 40000 ). Nominal support in these parts for full sovereignty has increased since the 1990 s, but still represents a minority view only. In Bonaire (10000), support for a country status within the Kingdom has more support now than before but, consistent with previous polls, a clear majority favours a direct link with the Netherlands. On Saba, with its 1400 inhabitants, an even more outspoken majority opts for this outcome. Surprisingly perhaps, the third Windward island of St Eustatius (2300 people) still harbours a clear majority for a continuation of the five-island Antilles. The only alternative option attracting significant support is, again, a unilateral link with the Netherlands.

The overall conclusion must be that the vast majority of the Antillean electorate have no confidence left in the five-island nation. In this they concur with their political leaders. Interestingly, they were not of the same opinion in 1993-94, when clear majorities in all islands still voted in favour of a continuation of the Antilles-of-five, even if the great majority of Antillean politicians advised them otherwise (Oostindie and Verton, 1998, p. 49). Then the proportion in favour of a continuation of the Antilles-of-five was over $85 \%$ for the three smallest islands, $73.6 \%$ for Curaçao and $59.4 \%$ for St Martin, while the independence option was chosen by less than $1 \%$ on all islands, except for St Martin (6.3\%).

Why did patience with the federally structured Antilles wane? One reason advanced by many observers may have been that, in 1993-94, the electorate was largely expressing its lack of confidence in local leadership. Even so, while the character and quality of this leadership has not changed significantly over the past decade, Antilleans do feel today that each should go its separate way.

Basically this all started with St Martin, always the least enthusiastic partner in the Antilles-of-five. Once the St Martiners had in 2000 voted squarely in favour of separation, the rest simply followed, with only St Eustatius ('Statia') in vain opting against change. It should be noted that the argument in favour of a break-up centres on bureaucratic and political issues. All islands complain of the dominance of Curaçao, while Curaçao in turn feels the federation to be burdensome to its own development. Apparently the question of whether the colonial construct of a five-island nation over the centuries has really become a nation, or should work towards this, is no longer deemed relevant. This was very different after 199394, when the Antillean government made some efforts to restructure the fiveisland state and advocated concomitant nation building (Commissie Natievorming, 1996).

The Dutch have never been enthusiastic about the prospect of having to entertain separate relations with six small to absolutely tiny islands and only reluctantly agreed to the separation of Aruba first, and the further demise of the Antilles next. They have done so because they feel there is no willingness whatsoever left among the five islands to work together and that, moreover, inter-insular strife further diminishes the quality of Antillean governance. The Hague once again expects a trade-off now, in the form of a strengthening of the Kingdom's institutions within Caribbean government for most practical purposes, this will mean more Dutch control, perhaps mitigated by partial repairs of the 'democratic deficit'. Whether this can be accomplished within the parameters of the present Statuut is still a matter of debate. A promising 2004 


\section{2}

bilateral position paper on the subject suggests it can. But its lukewarm reception on the islands does not inspire much confidence (Werkgroep Bestuurlijke en Financiële Verhoudingen, 2004). Unfortunately, Aruba was not invited to participate in this commission, and therefore may have felt little obligation to contribute to its realization.

Arduous negotiations in 2005 led to a provisional agreement, which the islands hope will materialize in a permanent new status by mid-2007 (Hoofdlijnenakkoord, 2005). In the agreement The Hague only states that it is aware of the desire of Curaçao and St Martin to attain country status by 1 July 2007. The programme now is for both Curaçao and St Martin to attain autonomous country status within the Kingdom, while the small three will entertain direct relations with the Netherlands - Statia has explicitly agreed to what it now feels is inevitable, the full disintegration of the Antilles-of-five. Yet there is no clear conception as yet of what this arrangement would be like in practice. Curaçao and St Martin opt for a status equal to autonomous Aruba, but The Hague has strongly argued that autonomy needs to be limited in favour of more prerogatives to the Kingdom in the first place. The smaller islands could be some sort of municipalities within the Kingdom; but can there be municipalities without a provincial layer of government? To complicate matters, The Hague insists that any arrangement for a break-up of the five-island country should include a restructuring of the national debt, which now stands at a staggering $96 \%$ of Antillean annual GNP. And, finally, we have Aruba, distrustful of any change that might affect its own best-of-all-possibleworlds status, and which has the right to veto any changes to the Charter it feels them to be unfair or unwise.

\section{THE ANTILLEAN PREDICAMENT}

While the text of the Statuut has remained cast in stone for 50 years, contextual changes have been afoot. The major change is demographic. The numerical imbalance between the population of the Netherlands (now 16 million) and the six islands (180000 in the Antilles and 90000 in Aruba) has become even more pronounced. Moreover, with some 130000 islanders having settled in the metropolis in the past two decades, the Antillean and Aruban population is now fully transatlantic. This has consequences for the islands and the migrants themselves, consequences that local politicians tend to ignore. What once were only Caribbean questions and problems such as local unemployment, local criminality, local poverty - are now also Dutch problems.

The second changed parameter is the institutional setting. In 1954 the legislator spoke of self-governing partners under the umbrella of one Kingdom. Since then the small Caribbean partners have tenaciously hung on to their autonomy, while the largest partner has transferred a major part of its sovereignty to the European Union (EU). The progressive Dutch incorporation into the EU now obliges the islands to consider what further consequences they must draw from their refusal to opt for independence. In local debates on this question - such as on the possible choice for the status of an ultra-peripheral territory of the EU - one observes an anachronistic obsession with autonomy and an unwillingness to face up to the new geopolitical realities among most local politicians. This attitude seems self-defeating as well as 
risky. As observers in Brussels often remark, the more the EU spreads eastward, the more Brussels' willingness to accommodate the former West European colonies is likely to come under scrutiny.

Yet, in spite of the evident asymmetry of demographic, economic and geopolitical realities, the words of the original Statuut persist. The Caribbean partners continue to exercise the right to veto any changes proposed by the Dutch that they do not consider to be in their best interests. This deadlock may not continue indefinitely, however. The Hague is becoming weary of the many problems and few successes of its Caribbean policies, which in the Dutch press and in political circles alike are routinely characterized as an arduous 'muddling through'. The Dutch electorate too has become more aware of the Kingdom's bonds, and evaluates these mainly in negative terms. There is little sense of solidarity: clear and consistent majorities of the Dutch would prefer the islands to become independent today rather than tomorrow (Oostindie and Klinkers, 2001, Vol. II, pp. 38-39, 73-75; Vol. III, pp. 67-69, 231-232). In fact, one may well conclude that over the past half century Dutch politicians have been more accommodating of the islands than their own electorate would have liked. The recent attempts to curtail free immigration from the Antilles are a remarkable exception to this rule. Domestic problems connected with the lowerclass Curaçaoan exodus to the Netherlands have only compounded this negative attitude.

Across the Atlantic the Antillean people and their political elites, aware of the Suriname experience, of the growing US influence in the region, and of the onset of a global climate more disposed towards 'free trade', do not want to lose their umbilical cord to the Netherlands. As was confirmed once more in the recent plebiscites, support for political independence is negligible on all islands except, to some degree, St Martin. Antilleans and Arubans fear the loss of their privileged position if they should agree to even the smallest of changes to the Statuut, let alone to a transfer of sovereignty. Yet their facing up to a common (former) colonizer does not imply mutual solidarity. In their encounters with The Hague Antillean politicians may readily emphasize the communality of their Antillean and wider Caribbean culture, but in their political behaviour, insularity rules.

While politicians on both sides of the ocean continue negotiations over the dismantling of the Netherlands Antilles and the formulation of a new balance between Kingdom institutions and Caribbean autonomy, a political backlash in the Netherlands is evident. The May 2005 Dutch decision to prepare legislation to restrict migration from the Caribbean territories to the metropolis is illustrative. Admittedly these restrictions, once legislated, would only apply to specific problematic groups of immigrants. Even so, and on very good grounds, Antilleans and Arubans, who value the right of abode in the Netherlands as one of the principal arguments for their adherence to the Kingdom, perceive this new policy as a slap in the face. As it is, both judicial and pragmatic objections may well prevent this intended policy from materializing (Oostindie and Klinkers, 2003, p. 196). It is ironic that the UK has moved in exactly the opposite direction.

Perhaps some Dutch politicians naively hope that the offence will provoke Antilleans to reconsider membership in the Kingdom. More probably the assertive Dutch policy on the migration issue will only poison the climate in which the delicate issue of a rearrangement of autonomies and overarching responsibilities within the Kingdom is discussed. The outcome of this new round of skirmishes is not yet clear. 
Certainly the unilateral Dutch interventions have aroused animosity and provoked much anti-colonial rhetoric. The 'recolonization' concept has become an accusatory buzzword over the past decade. Antillean politicians are renowned for standing up vocally to The Hague and they may benefit from this, further complicating the arduous negotiations on a reform of the Kingdom and a planned break-up of the Antilles. But there is no indication whatsoever that this will translate into any significant support for a pro-independence nationalism.

So what may be expected? Independence is not on the agenda. Direct political subordination of the Caribbean islands (as in counties, municipalities or provinces) is a problematic option. Both Curaçao and St Martin are reluctant to let go of the present autonomy accorded to the Antilles-of-five. They prefer to inherit the same freedoms and competences Aruba did in 1986. Conversely The Hague is not really interested in transforming the Caribbean territories into fully integrated parts of the Kingdom. Dutch politicians are reluctant to return to the driver's seat after half a century of Caribbean autonomy. Moreover, they do not like the idea of possibly having to finance - as France does - a European lifestyle in the Caribbean.

Most probably The Hague will continue its policy of strengthening the institutions of the Kingdom and will in turn cooperate with the dismantling of the Netherlands Antilles as a single entity, a process that presupposes a modicum of mutual trust and pragmatism. From Dutch Caribbean politicians it requires the courage critically to assess what degree of autonomy really serves their islands' citizenry best. This is not necessarily the same degree of autonomy that matches their own personal interests and political convictions. Dutch politicians in turn may be expected to refrain from offering illusions to their own electorate wary of the Antilles in the first place. Thus, they will have to spell out that an eventual farewell to the Antilles is highly unlikely, that growth rather than a decrease in financial support is necessary, and that migration from the Dutch Caribbean will continue and should be accepted. This too requires a measure of courage.

Whatever the eventual political arrangements, the six islands will most probably experience a strengthening rather than a loosening of their transatlantic ties. While many Antilleans worry about the growing tendency for Dutch involvement as some kind of recolonization, the lack of any serious alternative to the present status precludes radical nationalist alternatives. This predicament translates into at times heated affirmations of insular patriotism which only underline the obvious paradox: much against their will, Antilleans today are more dependent upon the Dutch connection then ever before, a subordination only strengthened by their own choice of political insularism (Oostindie, 2005).

\section{WIDER IMPLICATIONS FOR SUB-NATIONAL ISLAND JURISDICTIONS}

Two broad concerns underlie this paper. The first, no longer controversial, is that there are a good many reasons why small, postcolonial territories may be wise not to opt for independence but instead to remain part of a larger state entity. For various reasons also the former metropolis may be expected to accept this decision to retain close ties. The second question is what degree of autonomy best serves the interests of these small, mainly island entities, non-sovereign 'jurisdictions' which, as Baldacchino (2006) argues, occupy the fuzzy middle ground between sovereignty and munici- 
pality. This second question, which incidentally refers not only to postcolonial territories, is both more complicated and more controversial than the first.

One refreshing and optimistic assessment of the advantages of maximum autonomy for such territories is Baldacchino's. He suggests that their status will stimulate flexibility among all parties involved. The metropolitan power - whether the UK, France, the USA or the Netherlands - offers an indispensable safety net and can exercise some form of 'soft imperialism'. But the Sub-National Island Jurisdiction (SNIJ) has "enough discretion to safeguard national identity, local culture and the general exercise of local power". For these SNIJs this apparent limbo is seen by Baldacchino (2004, pp. 77, 84; see also Baldacchino, 2006) as "a winning strategy in political economy". He therefore predicts that the next few decades will not witness "a flurry of independentist movements, but [rather] attempts by sub-national jurisdictions to carve out policy discretion on a specific number of areas in their favour".

My analysis of the Dutch Caribbean case supports this prognosis, but arrives at more ambivalent and indeed slightly more pessimistic conclusions. The major empirical evidence in favour of the 'winning strategy' argument is the dazzling economic development of Aruba after its separashon from the other Antilles. There is no doubt whatsoever that the new status at once greatly enhanced the island's flexibility and governmental efficiency and boosted local culture and identity. Aruba became a shining example both to Curaçao and to St Martin of what is possible with greater autonomy.

In contrast, there have been disturbing developments in the quality of governance itself on the islands, something that has clearly demonstrated the limitations of autonomous rule. Why is this? The central Antillean government's apparent unwillingness, or incapability, to redress corrupt governance on St Martin in the 1980s and early 1990s is one example. Similar problems emerged in Aruba in the 1990 s, and they continue with the present dramatic debt crisis of the Netherlands Antilles (Oostindie and Klinkers, 2003, pp. 131-152). In these and other cases, The Hague saw itself as obliged to interfere - not from any nostalgic urge to 'recolonize' the Dutch Caribbean, far from it. Since local politicians have failed to live up to acceptable standards of good governance, the Dutch drive to strengthen the prerogatives of the Kingdom, and hence their own involvement, was less a matter of virtue or desire than of a sense of duty and necessity.

It seems to me that there are many parallels here with the British policy for its overseas territories as executed over the past decades. One is that the same regional and insular problems have demanded a stepping-up of metropolitan intervention quite in contrast to the earlier policy of retreat. Another is that this new policy may be welcomed on the islands on pragmatic grounds, but at the same time arouses much local concern over autonomy and identity issues. This postcolonial predicament is hard to solve and will undoubtedly continue to arouse much controversy - as it does in the American and French dependent territories in the Caribbean (Hintjens, 2004; Ramos and Rivera, 2001).

One final observation seems in order here. Perhaps other small, non-sovereign territories have fared better than the Antilles. Perhaps, indeed, other such entities do not suffer to the same degree from the vulnerabilities which seem to characterize the Dutch Caribbean. Their small scale - extreme in the case of these six island jurisdictions - has aggravated a specific clientelist political tradition resulting in 
deficiencies in the quality of local governance. The freedom of movement inherent in the postcolonial relationship is adding to this through the brain drain towards the metropolis. In addition, and this is sheer bad luck, the geographical location of the islands in a zone of narco-trafficking places them, literally and metaphorically, in between the centres of drug production and drug consumption. The problem is that the islands' internal capacity to counter the corrupting influence of the drugs business and its associated money laundering is very limited.

This is indeed one of the main arguments in favour of strengthening postcolonial constitutional arrangements. It is also a major argument for stepping up the level of intra-regional cooperation, both within the group of sub-national island jurisdictions and between this group and the independent states of the Caribbean. While history teaches us that genuine cooperation within this highly fragmented region is hard to accomplish, we might expect metropolitan institutions to give a positive impetus in this respect.

While the fight against narco-trafficking comes to mind here first, we may also think of the development of legitimate economic opportunities, such as economically sustainable tourism. As it is, tourism has become the most important legal sector in most Caribbean economies, thriving without subsidies or special protective measures. Yet the ecological effects of mass tourism threaten to ruin the very assets on which it is premised. This affects both the independent Caribbean and its sub-national island jurisdictions.

In conclusion then, yes, there are very good reasons to celebrate the opportunities enjoyed by sub-national island jurisdictions because of their intermediate status. But these obvious benefits should not keep us from critically assessing the risks that can arise from granting too much autonomy to territories that may be too limited in human resources and governmental capacities to handle such autonomy, or to cope with its risks. Tailor-made solutions will be needed for these jurisdictions. Blessed with the option of not having to struggle on their own, these unique entities are unlikely to find general models to fit them or show them the directions in which they should go.

\section{Acknowledgements}

I thank Godfrey Baldacchino and David Milne for their stimulating criticism on earlier drafts of this chapter, as well as the anonymous reviewers for The Round Table for additional useful suggestions. Much of the empirical matter presented in this chapter is based on Oostindie and Klinkers $(2001,2003)$. More elaborate analyses, references and background materials to this brief sketch of Dutch Caribbean decolonization may be found in these texts.

\section{Note}

1. The Caribbean is generally defined as all islands in the Caribbean Sea, plus the Guyanas and Belize. The three Guyanas, while located on the northern shores of South America, have traditionally been inhabited and developed mainly along the Atlantic seashore, looking outward across the ocean to Europe and subsequently the Caribbean and the USA rather than 'down' to mainland South America. For centuries these coastal zones were therefore virtual islands, isolated from their South American neighbours. Of course, the informal 
regional expansion of Brazil and perhaps Venezuela may change this 'island status' over time. In fact, Belize, formerly British Honduras, initially shared much of this 'island orientation' across the Atlantic towards its colonial metropolis with the Guyanas. Over the past decades, however, both migration and political pressure from the surrounding Central American republics have broken this isolation, with mixed results for the local Anglophone population. This history may well repeat itself in the sovereign Guyanas.

\section{References}

Armstrong, H. W. and Read, R. (2000) Comparing the economic performance of dependent territories and sovereign microstates, Economic Development and Cultural Change, 48(2), pp. 285-306.

Armstrong, H. W., de Kervenoael, R. J., Li, X. and Read, R. (1998) A comparison of the economic performance of different micro-states, and between micro-states and larger countries, World Development, 26(4), pp. 639-656.

Baldacchino, G. (2004) Autonomous but non-sovereign? A review of island sub-nationalism, Canadian Review of Studies in Nationalism, 31(1-2), pp. 77-91.

Baldacchino, G. (2006) Innovative development strategies from sub-national island jurisdictions? A global review of economic policy and government practices, World Development, 34(5), pp. 852-867.

Bulmer-Thomas, V. (2001) The wider Caribbean in the twentieth century: a long-run development perspective, Integration \& Trade, 15(5), pp. 5-56.

Commissie Natievorming (1996) One People, One Effort, One Nation: Aanzet tot een beleidsplan voor de structurering van bet process van natievorming in de Nederlandse Antillen (Curaçao: Government of the Netherlands Antilles).

Hintjens, H. M. (2004) Governance options for Europe's Caribbean dependencies, The Round Table, 344, pp. 533-547.

Hoofdlijnenakkoord tussen de Nederlandse Antillen, Nederland, Curaçao, Sint Martin, Bonaire, Sint Eustatius en Saba (2005) mimeo, 22 October, Bonaire.

McElroy, J. L. and de Albuquerque, K. (1995) The social and economic propensity for political dependencies in the insular Caribbean, Social and Economic Studies, 44(2-3), pp. 167-193.

McElroy, J. L. and Sanborn, K. (2005) The propensity for dependence in small Caribbean and Pacific islands, Bank of Valletta Review (Malta), 31, pp. 1-18.

Oostindie, G. (2005) Paradise Overseas - The Dutch Caribbean: Colonialism and its Transatlantic Legacies (Oxford: Macmillan).

Oostindie, G. and Klinkers, I. (2001) Knellende Koninkrijksbanden: Het Nederlandse dekolonisatiebeleid in de Caraïben, 1940-2000, 3 vols (Amsterdam: Amsterdam University Press).

Oostindie, G. and Klinkers, I. (2003) Decolonising the Caribbean: Dutch Policies in a Comparative Perspective (Amsterdam: Amsterdam University Press).

Oostindie, G. and Verton, P. C. (1998) Ki sorto di Reino?/What kind of Kingdom? Antillean and Aruban views and expectations of the Kingdom of the Netherlands, New West Indian Guide, 72(1), pp. 43-75.

Payne, A. (2004) Small states in the global politics of development, The Round Table, 376, pp. 223-235.

Ramos, A. G. and Rivera, A. I. (Eds) (2001) Island at the Crossroads: Politics in the NonIndependent Caribbean (Kingston: Ian Randle and Boulder, CO: Lynne Rienner).

van Dijck, P. (Ed.) (2001) Suriname: The Economy - Prospects for Sustainable Development (Kingston: Ian Randle).

Werkgroep Bestuurlijke en Financiële Verhoudingen (Working Group on Governmental and Financial Relations) (2004) Nu kan het...nu moet het! (Now it's possible... now it should be done!) (The Hague/Willemstad: Ministry of the Interior and Kingdom Relations). 